\title{
Ensino e aprendizado na universidade: a percepção de estudantes em uma perspectiva fenomenológica
}

\author{
Fabíola Freire Saraiva de Melo ${ }^{1}$ \\ Bruno Miguel Carriço dos Reis ${ }^{2}$
}

Resumo: O crescimento do acesso ao ensino superior trouxe novas e importantes questões com as quais a universidade não estava preparada para lidar. A insatisfação manifestada por docentes e estudantes no âmbito universitário nos chama a olhar para a crise que se acentua. Para compreender tal questão, precisamos refletir sobre os diversos e diferentes elementos que constituem a sua problematização, destacando aqui os aspectos políticos, sociais, econômicos, mas, principalmente, os pedagógicos e psicológicos que podem nos ajudar a compreender tal problemática. Para tal, nos propusemos a perguntar aos alunos e alunas de uma universidade particular sobre essa experiência. Procuramos analisar a percepção destes acerca da instituição universitária (recursos e condições de funcionamento), das práticas pedagógicas (métodos de docência e relação com os docentes) e das suas expectativas pessoais e profissionais enquanto graduados. A investigação foi feita na perspectiva fenomenológica, que busca uma aproximação da experiência vivida e procura que a experiência se revele para conhecê-la. Assim, foram entrevistados oito estudantes de uma universidade particular, em dois grupos com quatro estudantes, com o intuito de conhecer suas percepções. A partir de seus relatos, identificamos três unidades de sentido que configuram existencialmente o fenômeno estudado: 1) "relação do aluno(a) com a

\footnotetext{
${ }^{1}$ Psicóloga, mestre e doutora em Psicologia da Educação pela Pontifícia Universidade Católica de São Paulo (PUC-SP) e pós doutora em comunicação pela Universidade Autônoma de Lisboa. Professora na Pontifícia Universidade Católica de São Paulo (PUC-SP) no curso de psicologia e pesquisadora do grupo "Fenomenologia, Psicologia e pensamento decolonial: ações clínica, educacionais e institucionais no contexto latinoamericano". E-mail: ffmelo@pucsp.br

${ }^{2}$ Doutor em Ciências Sociais pela Pontifícia Universidade Católica de São Paulo (PUC-SP) e em Ciências da Comunicação pela Universidad Rey Juan Carlos de Madrid (URJC-Espanha). Professor auxiliar na Universidade Autónoma de Lisboa (UAL-Portugal) e professor convidado na Universidad Autónoma de Querétaro (UAQ-México). É membro do Núcleo de Estudos em Arte, Media e Política (NEAMP/PUC-SP) e Co-coordenador do Núcleo de Investigação em Práticas e Competências Mediáticas (NIP@COM/UAL). e-mail: breis@autonoma.pt
} 
universidade"; 2) "relação do aluno(a) com professores" e 3) "relação do aluno(a) com o aprendizado". A relação do aluno com a universidade foi trazida pelos entrevistados(as) como uma relação muito importante, porém marcada por frustrações. Revelaram muita insatisfação com a estrutura da universidade, com as metodologias dos professores, com as exigências feitas por esses e com o sistema de avaliações a que estão submetidos. Um dos aspectos evidentes é a relação mercadológica com o ensino e o "novo" perfil de aluno que tem ingressado no ensino superior. A percepção dos estudantes acerca da universidade e seu processo de aprendizado toca em questões nevrálgicas da crise universitária e revela de modo explícito a necessidade de uma nova cultura universitária, atrelada ao contexto social de rápidas transformações e indeterminações a que os estudantes estão submetidos e com os quais não sabem lidar. Atrela-se a isso a necessidade de mudança no paradigma educacional de ensino dos docentes para que favoreçam uma aprendizagem dinâmica, significativa, e que possibilite a construção de projetos de futuro. Discutir sobre o sentido da universidade e refletir sobre o trabalho que enquanto docentes realizamos, constitui um processo imprescindível para melhorar o nível de conhecimento sobre nosso modo de ensinar, e o que ensinar, para que a universidade possa rever seu papel.

Palavras-chave: Ensino universitário, metodologias de ensino e aprendizado, percepção do aluno, expectativas de jovens, psicologia fenomenológica.

\begin{abstract}
The increase of access to higher education has brought important new issues that the university was not prepared to deal with. The dissatisfaction expressed by lecturers and students in the university context, invite us to look at the crisis that is getting worse. To understand this question, we need to reflect about the different elements that constitute the problem, highlighting the political, social and economic aspects, but specially, the pedagogical and psychological ones, that can help us to understand this problem. To this end, we (set out to ask) have asked the students of a private university about this experience. We seek to analyze the students' perceptions about the university (resources and working conditions), pedagogical practices (teaching methods and relationship with lecturers) and their personal and professional expectations as graduates. The research was done in the phenomenological perspective, which seeks an approximation of the lived experience and seeks that the experience be revealed to know it. Thus, 8 students
\end{abstract}


from a private university were interviewed, in two groups with 4 students each one, with the purpose of knowing their perceptions. From their reports, we identified three units of meaning that configure the studied phenomenon: 1) "students' relationship with the university"; 2) “students' relationship with lecturers" and 3) "students' relationship with learning". The students' relationship with the university was considered by them as very important, but full of frustrations. They revealed a great dissatisfaction with the structure of the university, with the lecturers' methodologies, with the demands made by them and with the evaluation system. One of the evident aspects is the business relationship between the education and the "new" profile of the student who is reaching the university. The students' perception about the university and the learning process touches on the central issues of the university crisis and reveals the necessity of a new university culture, linked to the social context of rapid transformations and indeterminations and with which they can not handle. This is followed by a need of change in the educational paradigm of lecturers to foster a dynamic and meaningful learning that allows the construction of future projects. Discussing the meaning of the university and reflecting about the work that we do as lecturers is an essential process to improve the level of knowledge about our teaching, and about what teach. This is the way for the university can review its role.

Keywords: University teaching, teaching andlearningmethodologies, students'perception, young's expectations, phenomenological psychology. 


\section{Introdução}

Uma reflexão acerca das práticas da modernidade deve começar pelo questionamento dos sistemas de ensino. Marca indelével dessa constatação é a insatisfação manifestada por docentes e estudantes com as instituições educacionais. Aagudização dessa perceção no âmbito universitário por parte dos agentes sociais diretamente implicados com este sistema nos chama a olhar para a crise da identidade docente e das instituições universitárias, conforme propõe Goergen (2000). Para compreender tal questão, devemos procurar a sua compreensão em diversos e diferentes elementos que constituem a sua problematização. Pretendemos aqui destacar os aspectos políticos, sociais, econômicos, mas, principalmente os pedagógicos e psicológicos que podem nos ajudar a compreender tal problemática. Para tal, nos deteremos nessa discussão no quadro da massificação do ensino universitário que potencializou renovadas formas de organização das instituições universitárias, reconfigurou o papel das mesmas e propôs novas práticas, alterando a relação com os alunos e alunas ${ }^{3}$ e potencializando uma lógica cada vez mais clientelar (Bertolin, 2009).

Tais reconfigurações operam diretamente na praxis escolar, assim, pareceunos oportuno investigar como os alunos de uma universidade privada ${ }^{4}$ de Portugal têm percebido o ensino neste contexto de massificação. Tentamos analisar a percepção destes acerca da instituição universitária (recursos e condições de funcionamento), das práticas pedagógicas (métodos de docência e relação com os docentes) e das suas expectativas pessoais e profissionais enquanto graduados. Importa ressalvar que essa investigação foi feita na perspectiva fenomenológica que busca uma aproximação da experiência vivida (Moreira, 2002; Martins e Bicudo, 1989) e procura "permitir que a experiência se revele para conhecê-la" (Barreira e Ranieri, 2013, p.455).

\footnotetext{
${ }^{3}$ Tentamos ao longo de todo o trabalho manter uma escrita inclusiva de gênero. Contudo, tal tarefa ainda é um desafio para qualquer texto, contudo, especialmente nos artigos acadêmicos, visto que há um limite de caracteres. Portanto, procuramos sempre usar termos sem gênero, como estudantes e docentes, ou trazer as duas formas (a/o), suprimir artigos quando possível e, analisar cada caso para evitar o naturalismo do masculino como termo genérico para se referir às pessoas.
}

${ }^{4}$ Universidade Autónoma de Lisboa. 


\section{Massificação do ensino e os novos desafios para a Universidade}

A redução da desigualdade de acesso ao sistema de ensino ${ }^{5}$ é uma transversalidade nas democracias ocidentais desde os anos 60 do século passado (Bourdieu, 1966). Com uma procura intensiva, o setor público não conseguiu atender à demanda favorecendo a expansão do setor privado. Bertolin (2009) constatou que este fenômeno se produziu em escala global, daí a importância de avaliar os impactos dessa mercantilização. Assim, em sua pesquisa, o autor se propôs a investigar o sistema universitário brasileiro de 1994$2003^{6}$. Dos resultados conseguidos, vale a pena ressaltar alguns deles, especialmente a nítida queda de investimento do PIB nas instituições de ensino superior ${ }^{7}$. Por outro lado, houve um crescimento na relação de discente por docente com doutorado. Contudo, tal crescimento se deu predominantemente na rede privada, mas numa clara estagnação a partir de 1996, e não teve praticamente nenhuma alteração na rede pública. Em relação ao tempo de trabalho dedicado dos docentes, um importante indicador de qualidade, os dados revelam que diminuiu o número de docentes com dedicação exclusiva e que aumentou os com dedicação parcial. No período investigado, notou-se ainda que não houve também aumento significativo em relação à produção de artigos e publicações científicas. Foi medido também alguns indicadores de equidade, tais como o número de atendimentos proporcionados às minorias ou à população em situação econômica desfavorecida, número de vagas por região do país, e evolução nos conceitos A ou B no provão por região do Brasil.

Para todas essas questões não houve nenhuma alteração significativa. Assim, a

\footnotetext{
${ }^{5}$ No contexto português, segundo estatísticas do Ministério da Educação de Portugal, em 1965 existiam 34 estabelecimentos de ensino superior público e privado. Em 1975 o número cresce para 47. No ano de 1985 estão registados 83 estabelecimentos de ensino e em 1995, cifram-se em 280. Em 2003, o número de matriculados no ensino superior já chegava a 400.000, enquanto em 1982 esse número não chegava a 100.00 (Vieira, 2001). Em 2016, segundo os últimos dados disponíveis no PORDATA, estão inscritos 356.399 alunos. Sendo que 297.884 estão matriculados em estabelecimentos de ensino público e 58.515 em instituições de natureza privada e cooperativa. Facto notório, é que assistimos na última década a uma quebra do número de alunos no sector privado, uma explicação plausível é o agudizar da crise subprime em Portugal, iniciada no ano de 2007. Para o efeito consultar: http://www.pordata.pt/Portugal/Alunos + matriculados+no +ensino+superior+total+e+por+subsistema+de+ensino-1017

${ }^{6}$ Para tal, o pesquisador consultou as bases de dados do IBGE, MEC, Banco Central, CNPq, Fapesp, Ministério de Ciência e Tecnologia e Seppir.

${ }^{7}$ No Brasil em 1989, os recursos destinados às Instituições Federais de Ensino Superior (Ifes) correspondiam a $0,97 \%$ do PIB e, gradativamente, foram caindo até atingirem em 2001 apenas $0,61 \%$ do PIB, ou seja, uma queda de 34\% no período (Sguissardi apud Bertolin, 2009). Assistimos a uma inflexão nessa lógica, entre os anos de 2004 e 2014, pois a despesa federal com a educação foi gradualmente aumentando cifrando-se em 2014 em 1,71\% do PIB, segundo os dados contidos no Boletim Legislativo no 26, de 2015.
} 
partir dos indicadores consultados o pesquisador aponta para uma clara opção política de priorizar o ensino privado como estratégia de ampliação do sistema. Contudo, alerta para o fato de que é também nas instituições privadas que se encontram os piores desempenhos de importantes indicadores de qualidade da educação, tais como o número discente por docente, os menores números de projetos de pesquisa e produção científica, a menor percentagem de curso com conceito A ou B no provão e as mais baixas taxas de docentes com dedicação integral. Assim, concluiu que a falta de evidências claras de melhorias, em termos de equidade, diversidade, relevância e eficácia, indicam que, no período estudado, a qualidade do $\mathrm{Sesb}^{8}$ não avançou de forma significativa. Ou seja, a medição e análise global do conjunto de indicadores sobre a educação superior brasileira aponta que, em tempos de mercantilização, houve um aumento e expansão no acesso à universidade particular, porém a qualidade do sistema não evoluiu. Excluindo as especificidades do sistema brasileiro, diagnósticos anteriores apontam para contornos semelhantes nos países com forte terceirização do ensino (Estevão, 1998).

Mas a reconfiguração da oferta educativa decorrente deste processo expansivo da procura por formação superior é apenas a ponta do iceberg de uma temática que se abre em distintas frentes. É importante assinalar a mudança estrutural no sistema de ensino europeu com a implementação do Processo de Bolonha. Procedimento iniciado em 1988, ocasião de elaboração da Magna Charta Univestitatum e que precedeu o Tratado de Bolonha, assinado em 1999, visando à criação de uma Área Europeia de Ensino Superior (AEES). A União Europeia visava a criação de um sistema competitivo no ensino superior da Europa que travasse o crescente interesse dos estudantes europeus pela oferta formativa norte-americana (Bindé, 2007) ${ }^{9}$, onde os conteúdos eram ministrados de forma pragmática e utilitariamente aplicáveis e onde existia a possibilidade de transferência de "créditos" dos ciclos de estudo e um curto prazo de tempo de formação (Bianchetti e Magalhães, 2015).

A par destas transformações organizativas universitárias que propõem novos desafios curriculares e pedagógicos, somam-se as dinâmicas societais que interagem diretamente com o campo de ensino. Maria Vieira (2001), estudiosa do fenômeno educacional, assinala como este processo de mudança da sociedade portuguesa propôs um "novo" papel para a universidade e seus alunos. A autora relembra que nas décadas

\footnotetext{
${ }^{8}$ Sistema para avaliar o Desenvolvimento e a Qualidade da Educação Superior Brasileira.

${ }^{9}$ A UNESCO no seu relatório do ano 2000, apontou que 10,29 bilhões de dólares foram “transferidos" para os EUA pelos estudantes europeus.
} 
de 70 a 90, o ensino superior garantia às classes dominantes conquistas de ascensão na estrutura social, enquanto que as transformações estruturais ocorridas no ensino superior privado a partir de meados de 80 trouxeram outras características específicas àqueles que ingressam. Por exemplo, em 1997, mais de 40\% dos alunos matriculados tinham como nível de escolaridade dos pais o nível primário e apenas cerca de $10 \%$ destes alunos tinham pais com ensino superior. Portanto, o contraste geracional dos níveis de habilitação acadêmica são sugestivos de grande mudança no perfil dos egressos e evidencia o quanto é recente a generalização da escolarização como modo de socialização. Contudo, a pesquisadora alerta para os "novos" riscos associados a esse crescente acesso: o potencial desemprego ou não obtenção de um lugar no mercado de trabalhos compatíveis com os saberes e competências adquiridas no ensino superior, caracterizando-se como um "novo problema social". Cabe ainda destacar a dificuldade destes jovens para encontrarem ocupações profissionais remuneradas que sejam compatíveis com os níveis de qualificação conseguidas, o que entorpece a entrada na vida adulta e a concretização de aspirações do domínio imaterial, tais como a independência, conjugalidade ou parentalidade (Carriço Reis e Sousa, 2017).

Tais riscos desencadearam uma mobilização de ações em busca de se adaptar à situação e, dentre estas, destaca-se a condição de "trabalhador-estudante", em que dada a perda dos fundamentos estabilizadores do emprego buscam antecipar a entrada no mercado de trabalho. Esta dupla condição tem consequências diretas na identidade destes estudantes que, nessa condição de "homem plural", ao invés de ter uma identidade unificadora, incorpora dimensões de dissonância e contradição que se manifestam na forma como estes estudantes representam e agem no ensino superior.

Será por isso importante perceber em que medida se reconfiguram as expectativas dos alunos universitários em relação ao seu futuro profissional. O estudo realizado pelos psicólogos Teixeira e Gomes (2004), a respeito da transição da universidade para o mercado de trabalho ${ }^{10}$, apontam que quanto mais envolvimento o educando tenha tido em seu percurso acadêmico, maior é a sua crença em sua qualificação e capacidade profissional e, portanto, sente-se melhor preparado e capacitado para a saída da universidade. Dentre as ações que os alunos consideraram relevantes estão as atividades práticas e não obrigatórias, tais como monitorias ou iniciações científicas. Contudo, tais atividades são eletivas e poucos são os alunos que as realizam, visto que dependem da

\footnotetext{
${ }^{10}$ Recorrendo ao relato de doze alunos formandos, seis do curso de Odontologia e seis do curso de Farmácia da Universidade Federal do Rio Grande do Sul.
} 
sorte de um professor que os informe ou chame para tais ações ou que tenha a iniciativa, de ir buscá-las. Todavia, tal "maturidade" é rara e inesperada, tanto pela faixa etária bem como pela ausência de capacidade de discernir e perceber a importância destas práticas para seu futuro profissional. Assim, os pesquisadores concluem a pesquisa sugerindo a necessidade de programas de atendimentos oferecidos pela universidade, que ajudem o aluno a se desenvolver mais plenamente no contexto universitário, bem como o preparem para a tarefa de transição e entrada no mercado profissional.

Dessa forma, o quadro acima traçado aponta para uma conclusão substantiva, uma enorme indeterminação nos projetos profissionais dos/das jovens. Diante de tal situação, nos pareceu relevante perguntar que importância dão à sua formação e quais as expectativas que os/as acalentam neste contexto que apresenta adversidades.

\section{Uma abordagem fenomenológica da aprendizagem: a formação}

\section{universitária na perspectiva dos alunos}

O objetivo desta investigação foi compreender o sentido do curso universitário para as/os estudantes. Isto é, apreender a relação que estabelecem, de modo geral, com o ensino e o aprendizado no ensino superior. Mais especificamente procurou-se conhecer:

- As estratégias metodológicas utilizadas pelos educadores para facilitar os processos de ensino e aprendizagem dos seus educandos(as), a partir da visão dos alunos;

- A percepção e nível de satisfação dos alunos(as) com seus professores(as), curso e universidade;

- O sentido que os estudantes dão para o conhecimento transmitido na sua formação profissional e como este se projeta nas suas expectativas.

Algumas das perguntas que nos ajudaram a apreender o objeto estudado foram: como aprendem os alunos(as), isto é, quais os facilitadores e estratégias de aprendizado que consideram eficiente? O que aprendem? O que esperavam e esperam aprender em um curso universitário? E ainda, qual o grau de satisfação com o aprendizado que estão recebendo na universidade? Que ferramentas lhe confere a universidade para enfrentarem o mercado de trabalho e a vida adulta? Que horizonte traçam para os seus trajetos biográficos?

Assim, tivemos como objeto de estudo identificar e compreender alguns aspectos sobre como se dá o processo de aprendizado dos educandos na universidade, bem como 
suas expectativas em relação ao seu futuro profissional e suas frustrações vividas na universidade nesse processo.

Para realizar este estudo, a perspectiva metodológica adotada foi o referencial fenomenológico que propõe uma série de peculiaridades em seu modo de realizar-se e também nos resultados em que irá apresentar. Husserl (1859-1938), seu fundador, propôs uma nova base para a ciência ao realizar uma revisão e reorganização radical das categorias "sujeito" e "objeto", ao colocar um novo fundamento para as ciências e filosofias como "resposta" à crise interna das ciências. Assim, ao propor a distinção das essências das coisas em "exatas ou quantitativas" - aquelas em que é possível a metrificação e precisão - e "inexatas ou qualitativas" - aquelas que, não por imperfeição metodológica ou do pesquisador, mas por sua própria especificidade, são inexatas e só podem ser descritas (Ribeiro Junior, 2003; Merleau-Ponty, 1999), inaugura uma nova perspectiva na produção de conhecimento. Tal distinção, embora aparentemente simples, foi revolucionária e teve desdobramentos diversos, trazendo um impulso considerável para o desenvolvimento das metodologias qualitativas (Turato, 2003; Chauí, 2001 e Martins e Bicudo, 1989).

A pesquisa em fenomenologia irá sempre investigar uma vivência, uma “experiência mundana" ou o significado de experiências vividas, e esse é o primeiro e indispensável procedimento metodológico (Ribeiro Junior, 2003; Creswell, 2014; Moreira, 2002) do qual decorrem os demais instrumentos que possibilitarão o acesso a tais vivências. Husserl propõe uma importante atitude para que se possa "voltar às coisas mesmas"11 e aceder a experiência vivida: a epoché ou a chamada "redução ou suspensão fenomenológica". Merleau-Ponty $(1999$, p.10) afirma que a melhor definição dada para "suspensão fenomenológica" foi feita por Eugen Fink, assistente de Husserl, ao falar de uma "admiração diante do mundo" e, complementa o autor, o maior ensinamento da redução é a impossibilidade total da redução, já que "não existe pensamento que abarque todo nosso pensamento" (Merleau-Ponty, 1999, p.11). Praticar a suspensão seria realizar uma profunda reflexão que revela nossos preconceitos para que deles estejamos conscientes. O conceito de epoché está entre os principais postulados da fenomenologia. Conforme apontam os pesquisadores DeCastro e Gomes (2011a 2011b) sua definição é complexa na obra de Husserl e, como não poderia deixar de ser, sua transposição para a pesquisa também. Em grande parte das pesquisas, a epoché está presente e tal "técnica"

\footnotetext{
${ }^{11}$ A volta às coisas mesmas é um grande lema da proposta husserliana que visava acessar os fenômenos sem as teorias, leis, categorias e conceitos prévios já postulados pela ciência quantitativa que impregnou o "espírito" ocidental em seu modo de perceber o mundo.
} 
se utilizada de modo claro, transparente e explícito, confere rigor à pesquisa e possibilita novas descobertas. Neste presente trabalho, a epoché estará como uma atitude que atravessa todo o pesquisar, desde o objeto que se estuda, ao procedimento escolhido e análise realizada, evidenciando-se, inclusive, pelo fato dos pesquisadores serem docentes universitários. Portanto, nesse modo de pesquisar não se irá partir de hipóteses acerca do fenômeno estudado, procurará se despir do que já se conhece a respeito do objeto investigado para que possa estar aberto a conhecer outros modos de experienciar do fenômeno estudado e, assim, contribuir com sua compreensão.

O fenômeno aqui estudado, ou seja, nosso objeto de estudo, foi o processo de ensino e aprendizado do aluno na universidade, bem como suas expectativas sobre sua formação. Como pesquisadores e também professores universitários a epoché é uma atitude fundamental nessa investigação, para que nossa própria experiência não nos impeça de compreender outros sentidos, bem como para provocar empatia em relação às vivências estudadas. Podemos dizer que o conhecimento produzido nessa pesquisa irá identificar, conhecer e revelar sentidos acerca do fenômeno investigado, como experiências singulares sobre o fenômeno vivido e, assim, prescinde da generalização, pois compreende toda e qualquer vivência como única. Entretanto, tal perspectiva entende que realizar uma investigação, desde que feita de modo rigoroso, é sempre ampliar a compreensão de uma temática estudada ao revelar uma, ou várias, de suas facetas e, sobretudo, revelar o sentido de uma experiência (Barreira e Ranieri, 2013). Elegemos aqui nesse estudo a um instrumento de acesso à dimensão existencial do viver e como tal pode ser considerado como uma técnica apropriada à pesquisa fenomenológica e existencial (Dutra, 2002).

Acerca da atitude do entrevistador que deve predominar na entrevista cabe destacar a "escuta suspensiva", denominação de Barreira e Ranieri (2013), em que se efetiva um modo peculiar de atenção do pesquisador ao entrevistado, um direcionamento que se dá à experiência tematizada e um vínculo intersubjetivo que ali se cria. Esta ação do pesquisador visa tirar o entrevistado de uma atitude natural e impessoal em relação ao objeto investigado para levá-lo a uma atitude pessoal. E, seria esse complexo "fenômeno da empatia", elucidado por Barreira e Ranieri (2013) a partir da obra de Edith Stein, que cria as condições que fundamentam e sustentam a validade científica da pesquisa.

Para a análise das entrevistas, nos pautamos na proposta de Merleau-Ponty (1999/1945) que segue três etapas: a descrição, a redução e a interpretação (Teixeira e Gomes, 2004; Creswell, 2014; Moreira, 2004). Na descrição, procura-se trazer o mundo conforme vivido pelos participantes, sua percepção, sem avaliação do pesquisador. Temos 
como produto deste momento a "primeira reflexão sistemática" que, embora não seja interpretativa, já é uma elaboração do pesquisador sobre as falas dos participantes. Aqui, o pesquisador após transcrição e/ou leitura exaustiva dos relatos, apresenta uma síntese compreensiva da percepção dos participantes sobre a temática investigada. A seguir, realiza-se a "redução eidética", ou "segunda reflexão fenomenológica", onde se buscam, a partir do debruçar-se sobre o relato ou de comparações entre eles, as partes essenciais do vivido acerca do fenômeno estudado. Não há aqui uma busca pela frequência de aspectos que se repetem em cada relato e sim as contribuições que se abrem como possibilidade de compreensão que podem ser destacadas dos relatos. É nessa hora que o pesquisador questiona e compara as diferentes entrevistas visando elencar semelhanças, diferenças e aspectos considerados fundamentais nos relatos que serão ampliados na análise. E, como último momento, ocorre a interpretação em que se busca pelo sentido do fenômeno investigado. Aqui se visa os aspectos fundamentais de compreensão do fenômeno a partir do que surgiu na descrição e redução. Discutem-se sentidos e significados implícitos, a estrutura significativa do fenômeno, confronta-os com a literatura, apontam-se novas possibilidades de compreensão ou intervenção acerca do fenômeno. Cabe ressaltar que esses momentos, embora distintos, não são nitidamente separados entre si, visto que é necessário retomar uma para avançar para a outra. E, por último, ainda a respeito da análise é importante dizer que o que se procura alcançar é o sentido que se revela, um desvelamento hermenêutico, do fenômeno estudado, aproximando-se aqui do pensamento heideggeriano (Heidegger, 2001) que propõe um sentido inacabado, objeto de uma reflexão exaustiva, que nunca poderá ser cristalizado e que possibilita uma explicitação da experiência estudada (Feijoo e Mattar, 2014) ou, como resume Critelli (1996), a pesquisa realizada na perspectiva fenomenológica é um meio de refletir sobre o mundo e dele abstrairmos conhecimento.

\section{Procedimentos metodológicos para coleta de dados de jovens}

\section{universitários}

Esse estudo se desenvolveu na faculdade de comunicação da Universidade Autônoma de Lisboa, curso de comunicação e jornalismo, situado na sede, no Palácio dos Condes do Redondo, em Lisboa, Portugal. A participação dos alunos foi voluntária e foram realizadas entrevistas em grupo, com dois grupos de alunos, sendo o primeiro 
com quatro alunos (dois homens e duas mulheres) e o outro, coincidentemente, também com quatro alunos, sendo dois homens e duas mulheres. O primeiro grupo se formou a partir do convite feito pela própria pesquisadora que foi diretamente até uma sala de aula, explicou a proposta e os avisou que estaria naquele mesmo dia em uma sala e em um determinado horário para conversar com quem se disponibilizasse. A explicação dada foi que estava ali para pesquisar a relação dos alunos com o ensino universitário e esclareceu ainda que tinha interesse no tema porque era professora universitária no Brasil. O outro grupo se formou a partir do convite de um dos professores da universidade, coautor deste estudo, que explicou a proposta a alguns alunos que trabalhavam com ele. Tal aspecto é importante de ser explicado, visto que o segundo grupo de alunos era predominantemente formado por alunos com maior envolvimento com a universidade e com os professores. Os encontros com os grupos tiveram a duração média de uma hora e meia a duas horas.

Foi elaborado um roteiro prévio de perguntas que serviram somente como norteador dos objetivos a alcançar com as entrevistas, visto que a condução do grupo foi livre e buscava uma narrativa o mais livre possível dos alunos. A pesquisadora iniciou o encontro se apresentando, explicitando o fenômeno investigado e apontando o objetivo do estudo: conhecer, a partir da perspectiva do aluno, como tem sido o ensino e aprendizado na universidade e a perspectiva de futuro que se desenhado a partir dessa experiência. Como nota adicional, a pesquisadora procurou esclarecer que o fato de não ser professora deles naquela universidade poderia facilitar o acesso ao tema estudado, bem como a sinceridade e liberdade nas falas e que esse seria um dos motivos para que as perguntas estivessem sendo feitas para eles e não para seus próprios alunos.

\section{Descrição fenomenológica da percepção dos alunos sobre a}

\section{Universidade}

A seguir, apresentaremos uma descrição fenomenológica da percepção dos alunos e alunas sobre a universidade. A partir de seus relatos construímos um texto sintético em que buscamos revelar do modo mais próximo possível aquilo que foi trazido por eles e elas, suas percepções sobre a universidade, tal qual a vivem e experienciam.

Oito estudantes participaram desse estudo e a idade variou de 18 a 25 anos, sendo a média de 21 anos. Em relação à moradia, apenas três dos alunos moravam na própria cidade de Lisboa sendo os demais residentes em cidades próximas. Apenas dois não 
trabalhavam, outros dois afirmaram realizar trabalhos pontuais e quatro tinham trabalhos com duração de, pelo menos, quatro horas diárias. A nota média no curso foi de 13,6 (020), sendo que a média dos alunos do grupo 1 foi de 12,5 e a do grupo 2 foi de 14,8 o que reafirma o dado enunciado pelo professor que convidou os alunos para o segundo grupo, apontando-os como alunos e alunas com "melhor desempenho" e "mais envolvidos" com a universidade. E, um último dado sociodemográfico importante é em relação ao nível de formação dos pais visto que apenas três dos alunos (37\% da amostragem) tinham pelo menos um dos pais com curso superior.

Tais dados já revelam algumas importantes características desses alunos, pois evidenciam um "novo" perfil do jovem na universidade: moram longe do local de estudo, trabalham e são, geralmente, os primeiros em suas famílias a cursarem o ensino superior.

\section{A experiência comunicada: ouvir para aprender}

Os alunos foram unânimes em dizer que a universidade é diferente do que esperavam e que se frustraram em diversos aspectos. Em relação à tais frustrações, os dois grupos se diferenciaram em alguns pontos e concordaram em outros. Ambos fizeram críticas à estrutura física da universidade, porém para os alunos do grupo 1 isto seria inadmissível especialmente pelo fato de ser uma universidade particular. O primeiro grupo de alunos avaliou a estrutura da universidade como "muito ruim", "indecente", e fez duras críticas ao restaurante da universidade e aos professores. Já o segundo grupo, não considerou tantos problemas na infraestrutura. Pelo contrário, elogiam a estrutura do campus e dos laboratórios, mas queriam ter técnicos e professores o dia inteiro na universidade.

Os dois grupos destacaram também como problemático o grande número de alunos na sala de aula, por volta de setenta alunos, e elogiaram as disciplinas em que as turmas são menores. Apontaram que em grupos menores o professor pode se dedicar mais aos alunos, bem como destacaram que essa própria estrutura facilita o aprendizado por também gerar constrangimento aos que ficam evidentemente "desinteressados", como afirma a aluna:

À partida já deviam ser grupos mais pequenos. Se os professores pudessem ensinar para grupos mais pequenos de alunos era bom. Os professores também iam vir com outra maturidade. Imagina numa aula com 20 pessoas, 15 estavam interessadas, as outras cinco iam-se sentir-se mal (...) (Aluna do grupo 1). 
Os alunos dos dois grupos também fizeram críticas aos professores, desde o que ensinam, como ensinam e o modo como avaliam esse aprendizado. Foram unânimes também em apontar o distanciamento entre a teoria e a prática, embora os apontamentos dos dois grupos questionem aspectos muito diferentes e apontem para propostas diversas.

Em relação ao que é ensinado, os alunos do grupo 1 fizeram diversas críticas às aulas e aos professores, porém estas foram mais sobre a competência e a metodologia dos professores, bem como as exigências feitas por eles em relação à cobrança de presença, participação em sala de aula, leituras e avaliações, do que propriamente ao conteúdo ministrado. Já os alunos do grupo 2 apontaram decepção com a estrutura curricular oferecida pela universidade.

Em relação aos professores, o grupo 1 afirmou estar insatisfeito e fez duras críticas. Consideraram que grande parte destes ou não era capacitado para estar na universidade ou não teriam habilidade metodológica para transmitir conhecimento. A metodologia das aulas foi considerada entediante e o perfil dos professores foi apontado como despreparados, desqualificados, ou como inábeis e impacientes, como pode ser visto nos relatos abaixo:

As habilitações dos próprios professores, cada vez tenho mais a sensação, que estamos a ser ensinados por pessoas que não têm habilitações para isso. Até mesmo a nível psicológico e ao fato de se ter de lidar com pessoas e motivalas, mas também dar-lhes uma formação e eu sinto que às vezes estamos a ser ensinados por professores que não têm formação (..) quem havia de pensar que numa faculdade, ainda mais privada, em que nós investimos no nosso futuro numa faculdade privada precisamente para sair do estigma da universidade pública, e mesmo assim parece que temos piores condições e piores professores (...) eu acho que ninguém ia pensar, pelo que nós pagamos aqui (Aluno do grupo 1).

Cabe destacar que quando esses alunos do grupo 1 foram questionados a respeito das qualidades de um "bom" professor, curiosamente, a professora citada como "boa professora" foi a que é considerada a mais "brava" e exigente da universidade. Os alunos relataram que sentiam medo dela, mas que aprendiam, admiravam seu conhecimento e, até mesmo, sua postura e método de ensinar.

Já o segundo grupo de alunos, avaliou positivamente a maior parte dos professores, mas isso não os impediu de fazerem críticas à metodologia de ensino de alguns docentes. Contudo, no sentido oposto aos alunos do "grupo 1", os alunos do "grupo 2", de forma geral, consideraram os professores competentes e qualificados, embora tenham avaliado que nem sempre estes conseguissem transmitir o que sabiam, ou não faziam isso de modo interessante e motivador. 
Ainda sobre as críticas às metodologias de ensino, vale ressaltar uma observação importante feita pelos dois grupos a respeito do modo como os alunos são avaliados e, principalmente, sobre o retorno e sentido destas avaliações para os alunos. Como relatam: E depois com essa falta de feedback eu vivo na mesma (...). Para o professor $\mathrm{x}$, se calhar tenho de dizer nos testes o que ele disse, "tintim por tintim", para o professor y, já percebi que ele gosta dos que pensam por eles próprios e desenvolvam um tema refletindo sobre ele. Nós é que temos de adivinhar isto, nós é que temos de analisar o professor nesse sentido, porque ele não dá feedback, nós não sabemos o que é que ele quer (...) e isso faz com que atrase um bocado a nossa evolução, não é? (Aluna grupo 1).

Sobretudo em conseguir dar-nos o feedback que nós precisamos para saber aquilo que precisamos de melhorar, conseguir analisar no sentido do nosso conhecimento e no nosso sentido pessoal porque as pessoas são humanas e por vezes têm os seus problemas, (...) eu gostava de ter um professor que dissesse "olha, precisas de melhorar isto, precisas de estudar assim, precisas de pesquisar mais aquilo" e isso não acontece, simplesmente dão-nos as notas e nós não sabemos em quê que falhamos, o quê que tínhamos de estudar mais (Aluna grupo 2).

Sobre as avaliações, os alunos do grupo 2 ainda trouxeram alguns apontamentos sobre os diversos modos de serem avaliados, ressaltando que há professores que pedem nas avaliações uma repetição do que foi transmitido e outros que solicitam elaborações ou construções de ideias.

Ainda nesse sentido, os alunos e alunas deixaram evidente o modo como as notas afetam seus comportamentos. Apesar de todos compreenderem que a nota é apenas um aspecto do aprendizado e que não revela totalmente o desempenho do aluno, não deixam de considerá-lo como uma forma importante de reconhecimento. E poucos foram os que conseguiram compreender seu aprendizado para além da quantificação. Os alunos sugeriram ainda que as notas fossem compostas de modos diferentes, isto é, não apenas pela soma de notas dos testes e trabalhos, mas que deveriam considerar aspectos subjetivos relacionados ao "esforço" dos alunos, como sugere:

Um professor não se deve limitar a dar a nota da soma, ou seja, o teste vale $50 \%$ e a frequência vale $50 \%$, eu acho que não deve ser dada assim, a nota final deve ser pensada ou seja não deve ser o resultado de uma conta que deve ser dado. Por exemplo, eu vi que ele se esforçou, eu ajudei-o também, e eu via que ele queria fazer, mas, não conseguia. Então, nesse caso (Aluno grupo 2).

Com relação às demais formas de controle utilizadas pelos professores, ou tentativas de conter o barulho da turma, os alunos citam estratégias que vão desde os 
constantes "pedidos", broncas e "sermões" dos professores, até a mudança de lugar (separando alguns grupos de amigos ou algumas pessoas específicas) ou pedido para saída do aluno da sala. As opiniões dos alunos sobre tais estratégias dos professores divergem. Todos concordam que tais atitudes são típicas de professores do secundário, sendo que alguns as consideram necessárias dada a postura dos alunos em sala, já outros consideram consequência da dificuldade do professor em "prender" a atenção do aluno.

Ainda sobre os modos de controle estabelecidos pela universidade, está a frequência nas aulas. A obrigatoriedade de presença e permanência nas aulas foi criticada pelos alunos e percebida como um fator que aumenta o barulho na sala de aula e ainda, atribuída como uma exigência do tratado de Bolonha, como expressa o relato abaixo:

(...) esta história também de haver barulho nas aulas e tudo mais, acho que também tem a ver um bocado com o Bolonha, de ter os cursos em três anos, uma das coisas é termos de vir a "x" aulas, senão "chumbamos" por faltas. Mas, parece que estamos nós na primária. Eu acho que isso para mim é das coisas que veio prejudicar. Se eu não quiser vir a uma aula, por exemplo, vamos imaginar que eu não queria vir a uma aula porque estava maldisposto ou porque tive um problema com alguém, se não tivesse Bolonha eu podia faltar à aula depois logo apanhava aquilo, com Bolonha não, se não viermos à aula levamos falta (Aluno grupo 1).

Outra crítica feita pelos dois grupos de alunos foi sobre a relação entre a teoria e a prática. Solicitaram mais disciplinas práticas, bem como um modo de ensinar que fosse mais "prático", ativo. Relaciona-se a isso o pedido por conhecimentos que sejam "úteis" e "aplicáveis" e apontam que se o conteúdo fosse ensinado desse modo, seria mais interessante para os alunos.

Como é que eu sei se tenho conhecimento se não o ponho em causa, em prática? Devia haver mais debates, é assim, eu aprendo as coisas e tenho boas notas, estudo, pronto, a maior parte de nós percebe as coisas e tem uma boa nota no exame, na frequência, tenho a cadeira feita com 18 , mas se eu não sou posta em causa, se não tenho de debater sobre um assunto, se ninguém discute, como é que sei que sei? (Aluna grupo 2).

(...) saindo daqui temos de ficar aptos para o mundo do trabalho lá fora, não há de ser sempre estudo e estudo e estudo, não pode ser sempre teórico, chega a uma altura que é prático e é isso mesmo que acontece nos cursos profissionais, eles trabalham tanto o teórico muito bem como o prático ainda melhor, porquê? Porque tem as aulas diretamente com pessoas que estão mesmo a trabalhar na área. Aqui não acontece talvez tanto, nós trabalhamos muito a teórica, não digo que não seja necessário porque é, porque sem bases não há crescimento, ou 
pelo menos um, crescimento bom, estável, mas (...) a meu ver, num ano inteiro só 3 professores é que tinham capacidades para dar as cadeiras que deram. (Aluno grupo 1).

Vários aspectos se entrelaçaram na descrição dos alunos e foram trazidos aqui separadamente por uma questão meramente didática. As dificuldades e frustrações apontadas foram colocadas, de modo geral, ora relacionadas às atitudes dos alunos e ora relacionadas à metodologia de ensino, ou à concepção de educação, dos professores. Nesse sentido, há ainda outras falas significativas sobre o papel do professor e suas estratégias metodológicas:

Talvez uma coisa mais dinâmica e que puxasse mais pelos alunos, invés de ser o professor a explicar, explicar, explicar. Uma coisa mais de fazer com que o aluno explicasse porque sempre puxa um bocado por nós e faz com que o nosso cérebro a mexer, a tirar conhecimentos tirados dali conhecimentos tirados de acolá e não tanto aquela coisa de termos de tirar o conhecimento de uma forma útil, acho que assim acho que acaba por ser mais dinâmico (Aluna grupo 1).

Tem que partir também dos professores estimular os alunos, porque vai sempre ter em todas as turmas alunos diferentes e cada vez a geração que está a vir, é cada vez menos interessada pelas coisas (Aluna Grupo 2).

Dentre as estratégias citadas pelos alunos como facilitadoras do aprendizado, estão os debates com convidados externos, atividades em grupo, exercícios de "reforço" ou "melhorias".

Os alunos reconhecem o desafio dos professores de ensinar, especialmente para turmas tão grandes e heterogêneas e por meio de uma única metodologia que atinja todos, como evidenciam vários relatos já antes citados, mas as sugestões que trazem como "solução" são superficiais e relacionadas, em geral, à didática ou metodologia utilizada, como no relato do aluno do grupo 1: "é um desafio, mas por exemplo utilizar uma linguagem, nem muito específica nem muito básica". Ou atribuem à necessidade do professor saber motivar melhor ao aluno.

Quando perguntado aos entrevistados sobre a possibilidade de diálogo entre eles e a universidade e entre eles e os professores, as falas são unânimes em apontar exemplos em que a direção os escutou e atendeu seus pedidos, mas quando se relaciona aos docentes, divergem:

E também torna-se um bocado problemático quando percebemos que um professor, especialmente a nível acadêmico, não deve ter começado a dar aulas ontem e já tem um método de ensino um bocado estruturado e agora do nada 
aparecer uma turma: “olhe mude o seu método de ensino porque não está a cativar os alunos" ... Nós também percebemos que isso também é complicado (Aluno Grupo 1).

(...) nós dizíamos algumas coisas... [mas os professores diziam] "Não! O problema continua com vocês e com o barulho". Ficavam por aí, os professores (Aluno grupo 1).

Questionados a respeito do aprendizado e a relação com a idade dos professores, deixaram evidente preferir os professores com mais tempo de experiência de aulas e consideraram como mais velho, um professor acima de trinta e cinco anos ou com mais de dez anos de tempo de ensino.

Um aspecto muito importante trazido no relato dos alunos é o modo como abordaram a questão da "postura de estudante". Embora nas falas dos alunos do grupo 1, tal aspecto tenha sido apontado como sendo importante para o aprendizado, no grupo 2 , esta foi ressaltada e longamente discutida entre eles:

O que nós mais notamos aqui é que existe um esforço muito menor da parte dos alunos, do que dos professores. Estou a falar de uma maneira generalista (...). $\mathrm{Eu}$ acho que existe uma boa vontade por parte dos professores, em tentarem adaptar-se aos alunos. Às vezes, os alunos é que parecem que estão à espera que a nota caia do céu (Aluno grupo 2).

(...)o que eu acho que lhes vai na cabeça, na maioria dos meus colegas é "eu não tenho de mudar de atitude, o professor, é que tem de mudar a atitude porque eu lhe estou a pagar", exatamente é mesmo isto. É uma universidade privada, então, se quero ter a atitude de estar as duas horas de aula no Facebook, tenho de estar as duas horas de aula no Facebook e o professor agora arranja uma maneira de a matéria chegar até a mim. E, eu vou a tirar selfies e fotografias. Portanto, isto não tem de ser a posição de um aluno universitário que quer sair daqui com uma licenciatura (Aluno grupo 2).

A minha postura nas aulas é, normalmente, estou sossegada num canto, caladinha... estou com atenção e estou sempre a tirar apontamentos e notas, essa é a minha postura. E eu acho que isso diz tudo, não é? Diz que estou presente e que estou interessada, que estou ali para aprender. Há pessoas que são mais de intervir e que gostam de falar, gostam de debater, são posturas diferentes. $E$ o que acontece é que depois pode haver tendência para generalizar, portanto, "para mim a postura ideal é o aluno que intervém, que diz que está lá". E pronto, alunos que até sabem, somos um bocado desvalorizados nesse aspecto. E depois há alunos e alunos (Aluna grupo 1). 
(...) os alunos por vezes são espelho dos professores, sim, no sentido de que eles têm capacidade de fazer de nós aquilo que eles querem que nós sejamos, mas têm de o faze-lo, portanto, um professor que não é assertivo, que não é rígido, não é embucha, nós vamos ser assim, vamos ser assertivos (...) (Aluno grupo 1).

Ainda sobre a participação do aluno no processo de aprendizado, os estudantes trouxeram observações importantes relacionadas à diversidade de características dos alunos que compõem uma mesma sala de aula.

(...) sou a primeira da minha família a vir para a universidade (Aluna grupo 2).

(...) a questão é que nós estamos numa universidade privada e existem aqui pessoas que tem um nível de vida superior, um grande nível de vida, que estão habituados a terem tudo, e não estão habituados a esforçar-se por alguma coisa, um objetivo na vida e quando lhes pedem um bocadinho de esforço, queixamse (Aluno grupo 2).

Sobre as atribuições a que os alunos estão submetidos, também divergem para os dois grupos. Nesse sentido, cabe destacar a questão da leitura. Os alunos criticaram o modo como os professores indicam as leituras, pois se sentem perdidos com a quantidade indicada e exigida e relatam dificuldades para relacioná-las com o andamento das aulas.

Questionados sobre o tempo dedicado à universidade (para além da sala de aula) com leituras e estudos, os alunos, de forma unânime, seja os que trabalham ou os que não trabalham, disseram dedicar-se de uma a duas horas por dia, durante a semana, sendo somente em períodos de provas que essa rotina se torna mais constante. Alguns alunos fizeram ainda questão também de especificar a importância de utilizar o tempo para outras atividades desconectadas com a faculdade. O final de semana também foi apontado como um momento em que podem "tirar o atraso" ou se dedicar mais à universidade, especialmente, no período de testes, contudo, não seria necessariamente um momento de estudos.

Num dia normal, com os trabalhos e tudo à mistura, eu pessoalmente, só costumo ter tempo a partir das 11 da noite, e depois acordo às 6 da manhã, tenho um bocado limite, mas por dia, tirando aquelas noites que tem mesmo de ser uma direta e assim, uma a duas horas por dia (Aluno grupo 1).

(...) gosto dessas coisas que se calhar não estão muito relacionados com a faculdade porque lá está, já passo demasiado tempo na faculdade (Aluno grupo $1)$.

Uma observação feita pelos alunos a respeito da postura dos alunos na universidade e o preparo para a vida profissional, também vale ser destacada: 
Eu não acredito que $10 \%$ desta turma vai ser licenciada ou ter emprego. Até podem acabar mais com licenciatura, mas não vão ter trabalho. Não vejo esforço aqui nas pessoas, não vejo, eu não imagino estas pessoas no mercado de trabalho, se eu tivesse uma empresa não lhes dava trabalho (Aluna grupo 2).

Uma proposta feita por uma aluna do grupo 1, e apoiada de forma unânime pelos demais alunos, foi a de criação de algum serviço de apoio ao aluno dentro da universidade. Eu acho que no ensino superior tinha que ter pessoas que nos pudessem dirigir nesse aspecto, por exemplo, eu no marketing tinha uma psicóloga sempre pronta para nos ajudar a decidirmos aquilo que queremos, porque às vezes andamos um bocado perdidos, à deriva sem saber aquilo que queremos para o nosso futuro, e andamos aqui a desengraçar, andamos aqui a fazer nada, portanto, e eu acho que tinha um acompanhamento psicológico nesse aspecto era importante, aqui não há. Por exemplo, eu tenho uma dúvida grande, eu não sei se devo continuar neste curso porque não tenho sentido muito motivada como estava, à espera de me sentir e começo a duvidar de estar aqui porque eu no fundo estou a trabalhar, para poder estar aqui e se isso não se reflete depois nas notas nem se reflete no meu interesse em geral pela área, então o quê que eu estou aqui a fazer? Poder ter um professor que faça isso, ter alguém na área que até faça isso, podia ajudar-me muito e isso dai, porque há muitas situações em termos de pressão na turma (Aluna grupo 1).

Para finalizar, cabe ressaltar que deixaram evidente o interesse pela universidade visto que se envolveram muito nas discussões. E, quando ao final perguntei se poderia apresentar seus relatos à universidade (mantendo, obviamente, o sigilo) todos concordaram e consideraram importante como um modo desta poder se aprimorar.

\section{Análise fenomenológica: sentidos desvelados a partir da}

\section{percepção dos alunos}

Feita a descrição fenomenológica dos dados, busca-se a partir da redução fenomenológica, retornar à pergunta de pesquisa para destacar na descrição realizada os significados e sentidos que se desvelaram nas falas dos alunos a respeito de suas experiências com a universidade e com o aprendizado. As unidades encontradas revelam a "essencialidade estrutural do vivido", ou seja, uma interpretação fenomenológica sobre os aspectos fundamentais que se revelam nessa experiência estudada. Trata-se de um agrupamento e organização de aspectos reveladores do modo como a experiência é vivida pelos alunos. Não se buscou aqui as diferentes representações da experiência e 
sim identificar os sentidos e significados que ajudam a compreender como se configuram existencialmente o fenômeno estudado (conforme propostas de DeCastro e Gomes (2011b) e Critelli, 1996). Destacou-se três unidades de sentidos, denominadas por desvelamentos de sentidos: 1) "relação do aluno com a universidade"; 2) "relação do aluno com os professores" e 3) "relação do aluno com o aprendizado".

Estes três desvelamentos se relacionam e se entrelaçam no modo como revelam o sentido da experiência vivida pelos alunos na relação com a universidade, visto que não são aspectos isolados. Isto é: o aprendizado ocorre, ou não, na universidade e mediado pelo professor, de modo eficiente ou não. E, o aluno apreende, ou não, tais conhecimentos a depender de sua própria interação e características pessoais. Cada um destes desvelamentos abarca outros sentidos específicos que compõem as conexões pessoais e as diversas elaborações que esse "núcleo" explicita. Os elementos nucleares, como eleitos aqui, não priorizaram a quantidade, ou a generalização pela média, de nenhum dos aspectos revelados, ao contrário, mesmo que seja em um único discurso, desde que trazido como relevante no mundo vivido pelo participante. A elaboração desses núcleos visa elucidar as vivências e clarificá-las de forma a nos aproximar de aspectos próprios do mundo vivido pelos participantes e a conhecer o que foi o mais "típico" dessa percepção. Desse modo, pretende-se ter uma compreensão geral, dinâmica e existencial da experiência tematizada e, ao mesmo tempo, perpassar pelas diferentes elaborações pessoais:

\section{Relação do aluno com a universidade}

A relação do aluno com a universidade apareceu como uma experiência intensa e ambígua. A entrada no ensino superior é permeada pela expectativa e pelo sentimento de conquista e parece ser a realização de um sonho que transcende o desejo pessoal e que aponta para uma "vitória" da família. Além disso, a universidade aparece no discurso dos alunos como a possibilidade de uma formação profissional que deverá garantir uma vida melhor. Envolta por tantas expectativas parece ser quase inevitável o sentimento de frustração. Os alunos decepcionam-se por não terem encontrado a estrutura ou o "ambiente" que imaginavam. A ideia de "ambiente" aqui deve ser entendida como o "clima" geral da universidade que envolve quer seja a estrutura, os alunos e os professores. Tal "clima" foi imaginado como muito diferente do ensino secundário. A estrutura física desapontouos, as atitudes dos colegas de classe e, em alguns âmbitos, os professores, embora não todos e não para todos os alunos. Todavia, apontam a universidade como um lugar onde 
encontraram conhecimento e a possibilidade de "evoluir", porém criticam muito o modo como isso é feito, em termos metodológicos. Mas, fica evidente também que há ainda o reconhecimento e um "gosto" pelo prestígio e status social de estar ali, bem como atestam que a universidade desempenha um papel importante em suas vidas. A própria localização da universidade é um aspecto importante, já que essa se encontra em um bairro privilegiado da cidade de Lisboa, fácil acesso pelo transporte público, visto que dos oito alunos, cinco moram fora de Lisboa, em cidades pequenas e próximas. O prédio da universidade é um antigo palácio de condes e mantém, restaurada, essa estrutura original. Nesse sentido, alguns dos estudantes fizeram menções e comparações às diferenças estruturais de outras instituições públicas onde estudaram. Relacionado a isso, criticam as salas de aulas com tantos alunos e atribuem à universidade o papel de proibir turmas grandes, com mais de vinte alunos, o que só acontece em algumas disciplinas.

Em suas narrativas, disseram também que encontraram ali professores com muito conhecimento, embora nem todos com a capacidade para transmiti-los. E, em termos de preparo para o exercício da atividade profissional, são unânimes em dizer que não necessariamente o curso prepara o aluno para o exercício da profissão, visto que julgam que alguns de seus colegas poderão até ser aprovados nas disciplinas, receber o diploma, mas não teriam maturidade ou responsabilidade para o trabalho. Além disso, alguns questionam se verdadeiramente os alunos que são aprovados nas disciplinas o são por terem apreendido o que foi ensinado ou apenas repetido, "desbobinado", como "papagaio".

Um aspecto positivo que os alunos ressaltaram foi a possibilidade de diálogo com a coordenação e direção da universidade que, embora com limites, sempre se propõe a ouvir e a buscar soluções para os problemas por eles trazidos. Embora nem sempre sejam solucionados, o fato de serem acolhidos em suas queixas, já parece indicar uma ação importante.

Uma proposta feita por um dos alunos, e prontamente acolhida pelos demais, é a necessidade de um serviço psicológico ${ }^{12}$ que os pudesse orientar ou apoiar em suas angústias da escolha profissional e nas dificuldades de aprendizagem. A necessidade por saber se estão, realmente, no curso "certo", bem como as angústias que acompanham essa escolha e o próprio percurso de formação, são questões com as quais os alunos não sabem como lidar. Relatam dificuldade para discernir o que seriam as dúvidas e desafios

\footnotetext{
${ }^{12}$ Esse serviço existe na universidade, porém os alunos desconheciam sua existência, o que evidencia, no mínimo, a dificuldade de comunicação entre a universidade e alunos e alunas.
} 
inerentes ao processo de formação, bem como se as dificuldades tais quais as vivem seriam indicativas de que estão no curso "errado" e estariam indicando a necessidade de mudar de curso. Além disso, as dificuldades de aprendizado também são desafios com os quais nem sempre conseguem lidar e acreditam que algumas delas poderiam ser melhor orientadas por um professor "tutor". Tal proposta explicita a necessidade de outros modos de apoio e serviços voltados ao auxílio do aluno dentro da universidade. Outro aspecto que os estudantes indicaram é que a possibilidade de realização de algumas atividades na universidade, para além das obrigações curriculares, tais como participar de pesquisa com um professor, possibilitam uma relação de maior proximidade com a universidade e aumentam a sensação de preparo e competência para o mercado. Tal percepção dos alunos corrobora, em todos os sentidos, com os dados da pesquisa de Teixeira e Gomes (2004) ao refletirem sobre jovens recém-formados, trazida na introdução deste trabalho.

$\mathrm{Na}$ direção oposta a essa, os alunos do "grupo 1" fizeram questão de ressaltar que já ficam muito tempo na universidade e que querem ter "vida" para além do curso. Criticam o tempo obrigatório das aulas e, desse modo, evitam participar de atividades da universidade fora do horário da aula, visto já considerarem excessivo, ou no mínimo que deveria ser suficiente, o tempo das aulas.

Assim, o discurso dos alunos parece apontar para questões centrais sobre o papel e a crise da universidade na modernidade. O aumento de instituições universitárias, bem com o aumento no acesso a estas, não veio, necessariamente, acompanhado da qualidade do ensino. Ao contrário, a degradação das condições de trabalho oferecida aos professores nessas instituições se revela em sua baixa remuneração, no tempo de dedicação à universidade e preparo das aulas, na quantidade de aulas que ministram, bem como na qualidade da formação destes. Tais aspectos são percebidos pelos alunos, embora sem conseguirem elaborar essa crítica ou relacionar com as condições de trabalho dos docentes, nos questionamentos sobre a ausência do professor à disposição sempre que ele precisa, ao perceberem que há docentes que não estão na cadeira condizente à sua formação, ou ao queixarem-se da insuficiência de técnicos nos laboratórios.

A frustração de alguns dos alunos também passa pela formação do professor. Este é um importante indicador de qualidade no ensino visto que perpetua a baixa qualidade da educação bem como indica a manutenção de um ciclo iniciado antes dele. Em relação à qualidade das aulas, bem como a didática para ministrá-las, este não é um aspecto atrelado somente à precariedade das condições do trabalho oferecidos pela universidade, pois está diretamente relacionado com uma concepção de ensino e não "apenas" com a 
estrutura universitária oferecida, aspectos que discutiremos adiante.

Cabe ressaltar também uma questão complexa trazida pelo aluno sobre o mundo do trabalho. O mercado profissional mudou o perfil de seus profissionais não sendo "apenas" o curso universitário a garantia para entrada no mercado de trabalho. Tais "exigências", paradoxalmente, não levam o aluno a uma maior inserção na universidade e sim a preocupar-se a estar fora dela o quanto antes, ou melhor, a estar nela e já fora, ao mesmo tempo, como indicou Vieira (2001) sobre o "homem plural".

Para finalizar, a análise do desvelamento "relação com a universidade" explicitou muitos outros sentidos que atravessam e constituem esse desvelamento "maior" em que foram agrupados. Essa relação revelou-se como pautada por sentimentos de alegria e conquista, pelo desejo de que seja um espaço de formação e possibilidade de ascensão social, mas também de frustração com aspectos que encontram na universidade e que tinham imaginado diferente, especialmente, a infraestrutura, a metodologia de alguns professores e as atitudes de "secundário" dos colegas de sala.

\section{Relação com os professores}

A relação dos alunos com os professores também se mostrou como uma experiência forte e controversa. Enquanto para um dos grupos, os professores eram, na grande maioria, capacitados para o exercício da docência, para o "grupo 1" vários destes não deviam estar na universidade, seja por falta de preparo psicológico, didático-pedagógico ou ainda em relação ao conteúdo da disciplina ministrada. A principal crítica feita pelos dois grupos de alunos foi sobre a didática ou metodologias utilizadas pelos docentes visto que nem sempre tornavam o conteúdo interessante ou motivador. Foi atribuído como papel do professor incentivar o aluno a se interessar pelo que é ensinado, sendo que divergiram em relação à "força" que estes teriam, pois para alguns estudantes essa é uma tarefa atrelada quase que exclusivamente às habilidades do docente, enquanto para outros, depende também, ou principalmente, de características e interesses do aluno. Deixaremos para adiante essa discussão, dada sua complexidade, acerca das metodologias dos professores, bem como suas concepções sobre o ensino e opto por trazer antes algumas das demais considerações feitas pelos alunos.

Dentre as estratégias de sucesso que ressaltaram estão aulas com conteúdos mais práticos, debates com "convidados" (profissionais da área trazidos pelos professores da disciplina), aulas com maior participação dos alunos, tempo de experiência docente e 
uma relação próxima ou de apoio oferecida por alguns professores, bem como entre os alunos. Algumas estratégias vistas como necessárias, porém ao mesmo tempo criticadas por serem típicas do ensino primário ou secundário, foram os debates valendo nota, atribuições feitas pelo professor do lugar onde sentar a alguns alunos de forma a separar os grupos de amigos para evitar a conversa entre estes, retirada do celular e, até mesmo, exclusão da sala de aula.

Ainda dentre as estratégias de aprendizado, as notas e avaliações aparecem como forma de manter o controle ou interesse dos alunos e desempenham um papel importante na relação do professor com os estudantes. Para alguns, as notas e avaliações quantificam o aprendizado e revelam importantes aspectos deste, sendo uma medida de reconhecimento dada pelo professor por seu aprendizado. Enquanto para alguns poucos alunos, são vistas como forma de abuso de poder e controle e não representam seu percurso na disciplina. Cabe aqui também ressaltar que os alunos afirmaram, e criticaram, que não recebem retorno de suas avaliações, testes e trabalhos, exceto já ao final do semestre. No mínimo torna-se curioso qual seria o sentido de avaliar os alunos se estes não têm acesso ao seu desempenho ou só o teriam para constatar a aprovação ou reprovação na disciplina cursada, quando já não resta outra opção exceto esta ou a realização dos exames finais. Aqui caberia revermos a análise feita por diversos estudiosos da educação e das relações de poder no âmbito educacional que discutem como a atribuição de notas e a realização das avaliações ainda cumprem prioritariamente um papel de poder, adaptação, submissão, disciplinação e vigilância. (Foucault, 1987; Veiga-Neto, 2003; Silva, 2010). Vale lembrar também que há diversos pesquisadores da área da educação que defendem a avaliação como uma importante estratégia para orientar a aprendizagem, sobretudo quando ganha sentido para o aluno como forma de conhecimento de sua própria aprendizagem, além de ser hoje cada vez mais discutido a importância de se inovar nos modos de avaliar (Hadji, 2001; Perrenoud, 1999, 2000). Contudo, pelo relato dos alunos, pelo modo como estão, ou não, sendo apresentados aos seus resultados, o sentido das avaliações têm sido classificações aleatória, arbitrária e, até mesmo, tirânicas que pouco contribuem com o processo de aprendizado.

Outro aspecto levantado pelos alunos acerca das estratégias de ensino foi em relação ao material indicado para leitura. Os estudantes afirmaram ficar perdidos diante das listas de leitura disponibilizadas pelos docentes no início dos cursos, pois além de serem muitas e extensas, não sabem qual seria mais indicada como leitura no início, meio ou fim do semestre do curso. Novamente, é possível perceber que um importante recurso 
pedagógico não tem sido utilizado como deveria, deixando de cumprir sua finalidade, além de também ser uma forma de exercício de poder. Aqui, o que pareceu é que não houve um predomínio intencional do mau uso e sim uma ineficiência metodológica. Nesse sentido, cabe acrescentar a experiência docente brasileira em que o/a professor(a) indica especificamente um texto (ou livro) para cada aula e entrega esse cronograma no início do semestre letivo para os estudantes.

Uma questão bem importante de ser discutida é a relação entre medo e aprendizado. Nesse sentido, cabe ilustrar com uma situação interessante citada pelos próprios estudantes. Eles reconhecem a professora mais temida como uma "boa" docente e "eficiente" por conseguir manter a sala sob controle, fazê-los prestar atenção e, consequentemente, aprenderem. E, sobretudo porque diziam que "ao final, acostumavam-se" com o medo e suas grosserias, e até mesmo aprenderam a "gostar" dela, pois era "só uma defesa" de uma "boa pessoa". Apenas uma aluna advertiu para o perigo de tal modo de atuar desta professora, que lhe provocava intencionalmente medo, bem como pôs em dúvida esse aprendizado dos alunos, mas grande parte dos estudantes reconheceu o medo como uma estratégia eficiente:

Para mim é medo. Quase toda a gente a adora, porque acabou realmente por funcionar este medo que ela criava, e resulta porque as pessoas ouvem a matéria, e depois percebem "ah, afinal isto é fixe". Ou então, simplesmente passam e também ficam contentes. Eu gosto dela, porque eu gosto do facto dela saber muito e dar matéria interessante e ajudar-me a ser uma pessoa melhor. Há pessoas que gostam porque passaram. Mas é medo que ela cria. (...) Agora, aprender? Perguntas alguma coisa agora. Eles lembram-se? Ouviram? São aqueles que ouvem e cospem (Aluna grupo 2).

Há aqui um aspecto importante a ser destacado visto que, muitas vezes, é exatamente por não ter se constituído como uma autoridade que um professor precisa lançar "mão" do medo como estratégia de controle, tal como destaca Arendt (1999) sobre essa questão. Para a autora, a perda da autoridade dos educadores estaria atrelada à uma crise política maior do mundo moderno, em que a tradição se perdeu e, portanto, a ausência de referências do mundo. Porém, ainda segundo a filósofa, há outros fatores, advindos principalmente das teorias psicológicas e pedagógicas que contribuem para a crise na educação, dentre eles a crença na pedagogia como a "ciência do ensino". Com o conhecimento produzido pela pedagogia, o professor estaria apto ao domínio de qualquer assunto particular, pois seria formado para "mediar" e "conduzir" qualquer processo de aprendizado. Tal aspecto obviamente resultou em um grave negligenciamento da 
formação dos professores, bem como no abandono dos estudantes; realidade que atingiu especialmente o ensino básico, secundário e as escolas públicas. Assim, mesmo que esse não fosse o caso específico de alguns dos professores da universidade, essas características estão presentes na vida educacional prévia dos alunos nas instituições pelas quais já passaram. E, essa já se constitui como a representação do educador, de forma geral, que trazem ou vivenciaram. Portanto, na ausência de autoridade, torna-se "necessário" como estratégia para o professor, o uso do medo. E, este se mostrou como eficiente visto conseguir manter, mesmo que sob coerção, os alunos atentos e escutando o que está a ser transmitido. Assim, transformar a violência em ferramenta de aprendizagem é, no mínimo, um aspecto assustador que revelam o desespero docente, seu despreparo e a ausência de reflexão, bem como um retrocesso do conhecimento pedagógico.

Há outras dificuldades e obstáculos enfrentados pelos professores que foram trazidos pelos alunos e que ajudam a compreender o "fracasso" no ensino. A quantidade de alunos na sala foi, por unanimidade, considerada como algo que atrapalha e dificulta. Ressaltaram também a heterogeneidade dos alunos, visto que alguns, por exemplo, vêm de um ensino técnico com ênfase em história ou ciências, ou com pouco conhecimento da língua inglesa, ou ainda, com motivações muito diversas para cursar a licenciatura. Aqui, podemos observar que os alunos, principalmente do grupo 2, atribuem à falta de maturidade, ou aos privilégios de uma condição econômica, a ausência de interesse de alguns alunos, bem como a falta de cooperação, dentre outras atitudes de desrespeito ao professor. As conversas, o barulho e a ausência de interesse dos alunos pelas aulas, leituras ou conteúdo ministrado são percebidos como aspectos que atrapalham o professor, sendo até mesmo reconhecido por alguns como algo que faz com que o docente fique desmotivado ou nem consiga, efetivamente, dar aula. Os alunos reconhecem, embora com uma crítica bem superficial, algumas das dificuldades que tornam um desafio para os professores ter de ensinar para turmas tão grandes e tão heterogêneas. Mas, não conseguem elaborar "saídas" para isso, exceto com proposições "mágicas" e ingênuas, que colocam na capacidade de motivação do professor "fazer com que o aluno se apaixone", ou em sugestões simplistas, tais como o uso de uma "linguagem nem muito específica, nem muito básica".

Assim, os estudantes tomam os "sintomas", o barulho e o desinteresse, como causa do problema, enquanto estes poderiam ser compreendidos como resultado de um sistema educacional em crise, como sugerem diversos estudiosos, dentre eles podemos destacar Paulo Freire, José Pacheco e Rui Canário. O modelo pedagógico vigente funciona com 
um currículo estruturado, separado por disciplinas, com carga horária previamente fixa e conteúdos previamente delimitados. Tal proposta pedagógica pressupõe a adaptação e submissão dos alunos aos métodos de ensino dos docentes, bem como aos seus conteúdos eleitos que serão "inquiridos" nas datas previamente estabelecidas por estes. Todavia, questionar esse modelo vigente, já tão cristalizado, é algo tão óbvio - e, ao mesmo tempo, tão distante na realidade das universidades - e só tornam mais evidente o fosso entre as necessidades dos alunos e o que os professores têm a oferecer. Vale ressaltar que não há aqui uma crítica específica a um professor, e sim de uma apreciação feita às metodologias de um sistema educacional que, inclusive, espera essa postura do professor. Praticamente desde sua fundação, a universidade mantém a mesma estrutura e concepção de ensino seriada e conteudista - inalterada que espera que o aluno, sentado em uma carteira em sua sala de aula, acumule uma quantidade fixa de informações, em seguida, despeje-os em uma prova, mesmo que saiba que amanhã eles não lembrarão de mais nada daquilo. Ora, não apareceu recorrentemente essa concepção de ensino no discurso dos alunos?

Cabe destacar que as estratégias de sucesso percebidas pelos alunos entrevistados, bem como suas críticas, estão contempladas nas metodologias ativas. Todavia, a concretização desses projetos requer toda uma reforma na estrutura universitária (física e administrativa), bem como capacitação docente que possa prepará-los para atuarem nessa perspectiva. Portanto, tal mudança apesar de “óbvia" e necessária, não é simples e nem instantânea e envolve diretamente a revolução tecnológica que vivenciamos nos últimos anos, porém, este aspecto deixarei para abordar no item seguinte em que discutirei a relação do aluno com o conhecimento.

Um último aspecto ressaltado pelos alunos, mas para o qual não elaboram uma crítica a respeito, foi o fato de não terem o docente disponível na instituição tal qual gostariam. Novamente aqui, os alunos percebem o sintoma, mas não conseguem discutir a causa. Aqui, portanto, cabe ressaltar as condições de trabalho a que estão submetidos os professores. Mal remunerados e sobrecarregados pelas exigências acadêmicas de pesquisa, publicação e grande atribuição de horas aulas, terminam por sacrificar a qualidade do ensino. A carreira docente passou por grandes mudanças e tem sido cada vez mais subjugada à lógica do modelo de negócios que precariza as condições de trabalho dos professores e espera sua "servidão", conforme ressaltam diversos estudos (Chomsky, 2014; Bertolin, 2009; Vieira, 2001; Fonseca, 2001).

Desse modo, a análise do desvelamento "relação com o professor" mostrou-se como uma relação complexa e ambígua, permeada por outros muitos sentidos que se revelaram: 
a frustração, o medo, o controle, a submissão, o descaso ou a admiração e respeito pelo conhecimento que tem o professor. Sobretudo, a metodologia e a concepção educacional revelaram-se como ultrapassadas por pautarem-se nas aulas expositivas e, consequentes estratégias de controle são necessárias para viabilizá-las. Os sentidos revelados indicam, portanto, que essa relação precisa ser revista, transformada e potencializada para que, efetivamente ocorram relações de ensino-aprendizado.

\section{Relação do aluno com o aprendizado}

A relação dos alunos com o aprendizado se apresentou como um modo de envolvimento e interesse pelo curso e conhecimentos transmitidos que envolveria um conjunto de atitudes do aluno. Porém, tais atribuições dos alunos foram compreendidas como algo bem diferente para os dois grupos de entrevistados. O "papel do estudante" em relação ao processo de aprendizado foi considerado fundamental nos dois grupos, porém, com ênfases diferentes e sendo entendido de formas diversas pelos entrevistados. Para o primeiro grupo, a postura de interesse do estudante pelo aprendizado parece ser uma consequência de ações do professor que deve incentivá-lo a aprender, enquanto para o segundo grupo, é algo a priori como atitude no processo de aprendizado. Isto é, para o primeiro grupo, interessar-se pela disciplina, leituras e conhecimento transmitido pelo professor é algo que decorre das atitudes do docente, de como este ensina e do que ensina. Enquanto o segundo grupo defendeu ativamente que há uma postura de estudante prévia, algo como uma "educação que vem de casa", que respeita o professor, o considera uma autoridade e busca se interessar pelo que está ensinando. Este segundo grupo também trouxe importantes considerações acerca da metodologia de ensino dos professores, porém não veem a relação com o aprendizado como algo que começa ou dependa principalmente do professor, ao contrário, acredita que este só poderia ensinar desde que o aluno se proponha a aprender.

Outro aspecto importante apontado pelos alunos entrevistados foi a decepção nas atitudes dos colegas dentro do contexto universitário. Havia uma grande expectativa de que por estarem na universidade, os estudantes teriam uma conduta "madura", de interesse pela formação, pelos estudos e, de forma geral, pelo ambiente acadêmico, que seria muito diferenciada do ensino secundário. Entretanto, ao se defrontarem com a realidade da sala de aula da universidade que como as demais salas onde estudavam sempre predominaram estudantes com estas mesmas atitudes - desinteresse pela aula, uso do celular, conversas 
etc - frustam-se por não ter ocorrido o "salto" de conduta imaginado que diferenciaria, radicalmente, o aluno da universidade daquele do ensino secundário. Fica, portanto, mais uma vez explícito o status que há em torno da universidade que a coloca como algo superior e diferenciado dos demais níveis de ensino. Se já é sabido, pelos próprios estudantes, que há uma crise geral que acomete a educação, porque no imaginário deles a universidade teria ficado fora dela? Parece que ainda se mostra muito atual a crença de que a universidade representa o Zeitgeist de uma época.

Dentre as ações que fariam parte da conduta do estudante estariam, para os dois grupos, participar das aulas, realizar as leituras, desenvolver o pensamento crítico e tirar boas notas. Aprender é apontado como um processo muitas vezes árduo e é sabido que envolve dedicação para além do tempo da aula. Contudo, grande parte dos alunos parece não ter esse tempo disponível, seja por considerar que já dedicam muito do seu tempo à universidade, ao estar por tantas horas na sala de aula, além de colocarem nessa conta o processo de locomoção, seja porque têm de trabalhar nas demais horas do dia. Quando questionados sobre o número de horas que se dedicam à leitura e realização de trabalhos da universidade, os alunos afirmaram ser de uma a duas horas semanais e que esse tempo aumentava nos períodos de avaliação. Assim, esse parece ser um dos grandes desencontros de expectativas e exigências na relação entre professores e alunos com o aprendizado. Isto é, enquanto o professor espera, supõe e "conta" com as leituras dos alunos para que ocorra o aprendizado de sua disciplina, o aluno não despende de tempo para tal, seja por falta de desejo ou por impossibilidade devido ao trabalho. Esse "desencontro" de atribuições é algo importante de ser considerado visto que o docente entende como condição para o aprendizado a leitura e a dedicação ao assunto estudado para além do que é oferecido na sala. Portanto, o que é colocado como condição para seu aprendizado não é algo que ele possa realizar. Tal desencontro tem sido um dos grandes elementos para o "fracasso" do ensino na universidade e mereceria ser considerado como algo que evidencia um "novo" modo de lidar com o conhecimento. O estudante "ainda" vai à universidade para aprender e adquirir conhecimento, porém frequentar a universidade não é mais, como já foi antigamente, a atividade central, ou exclusiva, na vida dos "novos" estudantes. A formação superior, bem como a relação com o conhecimento e aprendizado, adquiriu um novo sentido para o educando, próximo a um sentido complementar e mais atrelado à vida profissional.

Os entrevistados atribuíram as diferenças nas atitudes dos colegas, em serem participativos ou não, na origem e motivação pelo curso superior. Para eles, alguns 
estariam ali apenas porque os pais os obrigam, ou porque a licenciatura é só mais um produto que podem comprar. Enquanto para outros, o ensino superior seria a realização de um sonho ou de uma conquista que envolve um futuro profissional. Os alunos chamaram de "maturidade", ou falta dela, esse conjunto de ações dos alunos que envolvem desde o modo de estar na sala de aula até o tempo de dedicação aos estudos fora da universidade. Tal percepção, novamente nos remete ao "novo" perfil do aluno que acessa a universidade e o sentido atual que esta adquiriu no mundo globalizado, e nos levam a questionar, novamente, seu acesso e finalidade.

Relacionado a isso, embora não seja uma correlação feita pelos entrevistados, apontam que a universidade não prepara, necessariamente, o aluno para o exercício da profissão. Alegam que muitos dos alunos não teriam responsabilidade, compromisso ou ética e, portanto, não conseguiriam um local para trabalhar. Ora, tal premissa não é necessariamente verdadeira, porém denuncia o quanto o ensino universitário não se ocupa, ou não consegue, formar profissionais comprometidos ética e politicamente com a sociedade.

Os alunos trouxeram também a preocupação com a crise econômica e a reduzida oferta de emprego que o país vive e se inquietam em relação à incerteza de seus futuros profissionais. Tal incômodo é condizente com o atual momento econômico do país, e do mundo, mas também revela uma "nova" condição da universidade que é a de não garantir que o mercado absorva seus egressos, bem como em ter que oferecer "diferenciais" e "super qualificar" seus alunos para estarem compatíveis com as exigências do mercado.

A universidade, embora questionada em seu status de saber, ainda foi considerada pelos entrevistados como um local em que podem aprender e encontrar conhecimento. Entendem-se como ativos nessa busca, mas criticam os professores em seu modo de ensinálos, bem como naquilo que exigem deles. Há, visivelmente, uma grande discrepância entre o que os professores e alunos esperam sobre o aprendizado na universidade, bem como sobre o caminho para tal. Tal aspecto, mais uma vez, expressa a discordância e a distância radical de expectativas, e consequentes frustrações, entre educadores e educandos.

Assim, podemos dizer que a relação que os entrevistados relataram ter com o conhecimento está atravessada por suas próprias crenças e atitudes em relação ao conhecimento e, embora a universidade seja considerada um local onde encontrarão o conhecimento, tal percurso tem sido atravessado por suas dificuldades de aprendizado. E, a atuação dos professores, impregnados por uma transmissão tradicional de ensino, não conseguem contribuir com o desenvolvimento de habilidades necessárias para que possam vivenciar uma aprendizagem significativa. 


\section{Considerações finais}

A percepção dos alunos acerca da universidade e seu processo de aprendizado toca em questões nevrálgicas da crise universitária e revela de modo explícito que são impactados diretamente por ela e estão frustrados em suas expectativas. A crise com que se defrontam as universidades se apresenta sob múltiplas formas e permite caracterizá-las como estrutural, conjectural, política, econômica, social, intelectual e ideológica.

Discutir a universidade e refletir sobre o trabalho que fazemos nela, enquanto docentes, constitui um processo imprescindível para melhorar o nível de conhecimento sobre nosso aluno e sobre nosso compromisso com a qualidade no ensino e com a sociedade. Tal como indicou Fonseca (2001) a universidade só continuará a ser a sede por excelência do desenvolvimento, e do espírito crítico, se souber exercê-lo, antes de mais nada, sobre si mesma.

A relação do aluno com a universidade foi trazida pelos entrevistados como uma relação muito importante, porém marcada por frustrações. Dentre elas, a primeira que podemos destacar é a própria estrutura da universidade que não condiz com as expectativas que tinham e, principalmente, sentem subaproveitá-los. Além disso, revelaram muita insatisfação com as metodologias dos professores, com as exigências feitas por esses, com o sistema de avaliações a que estão submetidos e, ainda, à postura de descaso dos próprios colegas. Evidenciam dificuldades no processo de ensino-aprendizado e, claramente, reconhecem em seus esforços pessoais, ou na ajuda dos próprios colegas, a possibilidade de avançar nestas dificuldades. Preocupam-se com o mercado de trabalho, mas são poucos os recursos que encontram para enfrentá-los e entre as estratégias está "entrar" desde cedo nele. Assim, essa "nova" característica dos alunos, paradoxalmente, limita a dedicação à formação. Tal aspecto é também uma característica do "novo" perfil de alunos que acessa a universidade que, por este e outros aspectos ligados à condição sócio-econômica de origem, dificultam a imersão do aluno no ambiente acadêmico.

Fica evidente a necessidade de que a universidade propicie ambiente e situações de aprendizado que sejam dinâmicos, significativos e construtivos, os quais devem ser mediados pelo professor. Todavia, pelos relatos ouvidos que, evidentemente, são um pequeno recorte de uma universidade específica, de um ano e de um único curso, parecem nos escancarar que a universidade ainda está muito distante de oferecer tais possibilidades ao aluno; até porque os pesquisadores deste estudo podem afirmar por suas experiências que tais aspectos se mostram também em outras universidades em que 
lecionam. Tal mudança requer uma longa transformação no ambiente acadêmico. Dentre estas inúmeras, está, sobretudo, a necessidade de investimento na formação e atualização do professor, bem como em melhores condições de trabalho.

O crescimento do acesso ao ensino superior não foi acompanhado de crescimento na qualidade do ensino oferecido, muito pelo contrário, trouxe novas e importantes questões com as quais a universidade não estava preparada para lidar. O "novo" perfil do aluno que nela ingressa está entre as questões centrais que precisam resultar em novos projetos institucionais de apoio e instrumentalização de habilidades e competências básicas para o aprendizado. Ficou evidente essa necessidade, sugerida até mesmo pelos alunos, que requisitam apoio, psicológico e pedagógico, em seu processo de aprendizado. É necessário analisar e desenvolver estratégias de aprendizagem e implementar programas que aumentem a autonomia e motivação dos alunos. Atividades que melhorem a tomada de consciência e controle sobre o aprendizado contribuem com a qualidade do aprendizado e rendimento acadêmico. Quando o aluno percebe que tem controle de sua aprendizagem, que esta depende mais dele do que de fatores externos, ganha mais confiança e autonomia. Tais projetos, bem como atividades oferecidas pelos professores, são fundamentais para que possam propiciar ao aluno aprender, em um ambiente que valoriza a autonomia, levando à construção de conhecimento e fomentando o pensamento crítico.

Apareceu no discurso dos alunos a tendência à adoção de uma atitude passiva e que parece não estar se modificando. Nesse sentido, cabe destacar que a autonomia no aprendizado e o desenvolvimento de habilidades e estratégias de estudo não dependem somente dos alunos, ao contrário, são estratégias a serem aprendidas. Como sugerem diversos estudos e autores, citados ao longo deste trabalho, contribuem nesse sentido programas e projetos de tutoria que implementem e avaliem o desenvolvimento de competências básicas. Corrobora com isso, a percepção de que esse momento tem sido vivido pelos estudantes como importante para construção de projetos de futuro, especialmente pelo contexto social de rápidas transformações e indeterminações a que estão submetidos e com o qual não sabem lidar.

O docente foi reconhecido pelos alunos como a peça fundamental do processo de ensino-aprendizado, contudo já aparece também como alguém desautorizado, inábil e até mesmo incapaz para algumas das funções que exerce. Embora tais falas devam ser relativizadas e analisadas sob o contexto do "lugar" de aluno/a, deixam como urgente a necessidade de que sejam consideradas as metodologias e estratégias utilizadas por estes para que recuperem o lugar de agente dinamizador do aprendizado. 
Mostrou-se como imprescindível também a necessidade de se revisar e modificar os sistemas de avaliação, bem como critérios e instrumentos utilizados pelos docentes. A avaliação deveria ser uma forma de conhecer o aprendizado do aluno e suas dificuldades, todavia têm servido mais às relações de controle, submissão e poder, ou à reprodução mecânica das informações transmitidas.

A concepção de educação, bem como o sentido do ensino-aprendizado na universidade, tanto pelos professores como pelos alunos, estão fortemente impregnadas de uma concepção mecânica passiva e tradicional do ensino que, evidentemente, fracassa em atender as expectativas de ambos. Cabe destacar ainda sobre isso o enorme desencontro entre estes em relação ao tempo de dedicação aos estudos da universidade. O professor não só espera, mas inclui como condição de aprendizagem, um tempo que o aluno não tem, não pode ou não consegue despender, para a universidade. Assim, desde o início parecem partir de necessidades e expectativas diversas que só tendem a aumentar na medida em que esse encontro vai se realizando de modo penoso para ambos.

A reforma iniciada e indicada pela EEES e Alcue ${ }^{13}$ implicam em novos paradigmas conceituais e filosóficos, que devem resultar no planejamento de projetos interdisciplinares e intranacionais, acompanhada de mudanças na infra-estrutura universitária, qualificação e investimento no docente. Caso contrário, todo esse empenho não passará de declarações políticas de boas intenções que desperdiçam uma oportunidade história de cooperação transnacional (Herrera-Torres \& Lorenzo-Quiles, 2009). Tais revisões e mudanças estão diretamente atreladas à inserção de metodologias ativas, como a "Aprendizagem Baseada em Projetos" (ABP), que se mostram como uma tendência mundial desde o ensino infantil até o ensino superior (Bender, 2014).

Miguel Zabalza (2004) contribui nessa discussão sobre a necessidade de uma nova cultura universitária, que surge nesse momento de tantas transformações sociais, segundo a qual é imprescindível renovar o seu sentido e a sua missão. Os aspectos que destaca em sua obra parecem resumir e apontar direções para diversas questões que encontramos no discurso dos alunos e que levantamos como nossos dilemas a enfrentar: 1. Assumir uma nova visão do aluno e do processo de aprendizagem em seu conjunto. 2. Estabelecer objetivos a médio e longo prazo. 3. Manter uma orientação baseada no desenvolvimento pessoal. 4. Atualizar e dinamizar os conteúdos do currículo formativo. 5. Dinamizar o âmbito das metodologias empregadas. 6. Propiciar cenários contínuos de formação. 7. Incorporar ao currículo de atividades formativas extracurriculares.

\footnotetext{
${ }^{13}$ Alcue é a referência ao espaço America Latina, Caribe e Europa para cooperação universitária.
} 
FABÍOLA F. S. DE MELO E BRUNO M. C. DOS REIS $\underset{6}{6}$ ENSINO E APRENDIZADO NA UNIVERSIDADE (...)

Reconhecer as consonâncias que os dados desta pesquisa, bem como seus impactos, geram na prática docente dos autores deste trabalho é algo importante de ser revelado, pois devem servir para ampliar o campo de possibilidades a serem problematizadas e reconhecidas no ato da análise. Tal aspecto está em consonância com a metodologia fenomenológica que não assume uma postura de neutralidade, mas mantém-se atenta e em uma atitude de abertura para perceber e permitir que tais aspectos acrescentem na discussão do fenômeno.

Espera-se que possa contribuir com a reflexão sobre o sentido da universidade e o processo de ensinar e aprender, para professores/as e alunos/as, de modo a fomentar demais reflexões resultantes dos desafios suscitados pela percepção dos estudantes e o modo como têm experienciado e elaborado essa vivência de chegar ao ensino superior. 


\section{Referências}

ARENDT, Hannah. (2001) A crise na Educação. In: Entre o Passado e o Futuro. Trad. de mauro W. Barbosa. 5 ed. São Paulo: Ed. perspectiva, p.221-247.

BARREIRA, Cristiano R.A, \& Ranieri, Leandro Penna (2013). Aplicação de contribuições de Edith Stein à sistematização de pesquisa fenomenológica em psicologia: a entrevista como fonte de acesso às vivências. In: Mahfoud, Miguel e Massini, Marina (orgs.) Edith Stein e a Psicologia: teoria e pesquisa. Belo Horizonte: Artesã editora.

BENDER, William N (2014). Aprendizagem Baseada em Projetos: educação diferenciada para o século XXI. Porto Alegre: Penso.

BERTOLIN, Júlio Cesar G (2009). Avaliação da educação superior brasileira: relevância, diversidade, equidade e eficácia dos sistemas em tempos de mercantilização. Avaliação: Revista da Avaliação da Educação Superior (Campinas), 14, 351-383.

BIANCHETTI, Lucidio, \& MAGALHÃES (2015), Antonio M. Declaração de Bolonha e internacionalização da educação superior: protagonismo dos reitores e autonomia universitária em questão. Avaliação: Revista da Avaliação da Educação Superior (Campinas), 20, 225-24.

BICUDO, Maria Aparecida V.; MARTINS, Joel (1989). A pesquisa qualitativa em psicologia. Fundamentos e recursos básicos. São Paulo: Moraes/EDUC.

BINDÉ, Jérôme (Coord.) (2007). Rumo às sociedades do conhecimento. Relatório Mundial da UNESCO. Lisboa: Instituto Piaget.

BOURDIEU, Pierre (1996). "L'école conservatrice. Les inégalités devant l'école et devant la culture”, Revue Française de Sociologie, VII, p. 325-347.

CANÁRIO, Rui. (2012) Formação e desenvolvimento profissional dos professores. Consultado em 3/3/2016, em: https://crispasuper.files.wordpress.com/2012/06/ formdesenvolprofisprofes.pdf

(2009) Transformando problemas em soluções. Entrevista à Revista Gestão Escolar. Consultado em 01/3/2016, em: http://gestaoescolar.abril.com.br/ aprendizagem/use-crise-criar-482738.shtml

CARRIÇO REIS, Bruno M. e Sousa, J. (2017). A invisibilidade do desemprego juvenil no discurso mediático da imprensa portuguesa. Observatório (OBS*), 11, 134-148.

CHAUÍ, Marilena (2003). Convite à filosofia. São Paulo: Ática, 13ed.

CHOMSKY, Noam (2014) Entrevista concedida. Consultado em 2/3/2016, em: http:// cartamaior.com.br/?\%2FEditoria\%2FEducacao\%2FChomsky-Sobre-a-precarizacao-dotrabalho-e-da-educacao-na-universidade $\% 2 \mathrm{~F} 13 \% 2 \mathrm{~F} 30389$ 
CRESWELL, John W. (2014) Investigação qualitativa e projeto de pesquisa: escolhendo entre cinco abordagens. Porto Alegre: Penso.

CRITELLI, Dulce (1996) Analítica do sentido: uma aproximação e interpretação do real de orientação fenomenológica. São Paulo: EDUC: Brasiliense.

DeCASTRO, Thiago. G., \& Gomes, William. B. (2011a). Aplicações do método fenomenológico à pesquisa em psicologia: tradições e tendências. Estudos de Psicologia (Campinas), 28, 153-161.

(2011b). Movimento fenomenológico: controvérsias e perspectivas na pesquisa psicológica. Psicologia: Teoria e Pesquisa, 27, 233-240.

DUTRA, Elza (2002). A narrativa como uma técnica de pesquisa fenomenológica. Estudos de Psicologia (Natal), 7, 371-378.

ESTÊVÃO, Carlos (1998). Políticas de privatização e educação. Educação, Sociedade \& Culturas, $n^{\circ}$ 9, 69-94.

FEIJOO, Ana Maria L. C., \& MATTAR, Cristine M. (2014). A fenomenologia como método de investigação nas filosofias da existência e na psicologia. Psicologia: Teoria e Pesquisa, 30, 441-447.

FONSECA, Fernanda Irene (2001). Algumas reflexões sobre o discurso pedagógico universitário. In Encontro de Questões Pedagógicas, 1998, p. 135-142. Porto: Universidade do Porto. Faculdade de Letras. Consultado em 28/2/2016: https://repositorio-aberto.up.pt/ bitstream/10216/7783/2/5452.pdf

FOUCAULT, Michel (1987). Vigiar e Punir: nascimento da prisão. Petrópolis, Ed. Vozes.

FREIRE, Paulo (2002) A pedagogia do oprimido. Rio de Janeiro: Paz e terra.

GOERGEN, Pedro (2000). A crise de identidade da Universidade Moderna In: PEREIRA, Elisabete Monteiro de Aguiar; SANTOS FILHOS, José Camilo. Escola e Universidade na Pós-Modernidade. São Paulo: FAPESP, p. 101-161.

HADJI, Charles (2001). Avaliação demistificada. Porto Alegre: Artes Médicas.

HEIDEGGER, Martim (2001). Ser e Tempo. Trad. Marcia Sá Cavalcante. São Paulo: Vozes.

HERRERA-TORRES, LUCIA \& LORENZO-QUILES, Osvaldo (2009). Estrategias de aprendizaje en estudiantes universitarios. Un aporte a la construcción del Espacio Europeo de Educación Superior. Educación y Educadores, 12, 75-98. 
MARTINS, Joel \& BICUDO, Maria Aparecida (1989). A pesquisa qualitativa em psicologia: fundamentos e recursos básicos. São Paulo: Moraes.

MERLEAU-PONTY, Maurice (1999). Fenomenologia da percepção. Trad. Carlos Alberto ribeiro Moura. São Paulo: Martins Fontes.

MOREIRA, Daniel A(2004) O Método Fenomenológico na Pesquisa. São Paulo: Pioneira Thomson Learning.

PACHECO, J (2014). Diálogos com a escola da Ponte. São Paulo: Vozes.

PERRENOUD, Philippe (1999). Avaliação: da excelência à regulação das aprendizagens. Porto Alegre: Artmed.

(2000)10 novas competências para ensinar. Porto Alegre: Artmed.

RIBEIRO JUNIOR, João (2003) Introdução à Fenomenologia. Campinas: Edicamp.

SILVA, Tomaz T. (Org.) (2010). O sujeito da Educação: estudos foucaultianos. Petrópolis, Rio de Janeiro: Vozes, pp. 247-258.

TEIXEIRA, Marco Antônio Pereira; GOMES, William Barbosa (2004). Estou me formando... e agora?: Reflexões e perspectivas de jovens formandos universitários. Rev. bras. orientac. prof, São Paulo, v. 5, n. 1, p. 47-62, jun. Disponível em <http://pepsic. bvsalud.org/scielo.php?script $=$ sci_arttext\&pid=S1679-33902004000100005\&lng=pt\&n $\mathrm{rm}=\mathrm{iso}>$. acessos em 21 abr. 2018.

TURATO, Egberto R (2003). Tratado da metodologia da pesquisa clínico-qualitativa, São Paulo: Vozes.

VEIGA-NETO, Alfredo (2003). Foucault e a Educação. Belo Horizonte: Autêntica.

VIEIRA, Maria M (2001). Ensino superior e modernidade: algumas breves considerações. FORUM SOCIOLÓGICO, \#5/6, (2 ${ }^{\mathrm{a}}$ serie), pp. 169-184. Acessado em Fevereiro 28, 2016, em: http://forumsociologico.fcsh.unl.pt/Detalhes.aspx?ID=Ed5art9.html

VILELA, Rita A. T (2003). O lugar da abordagem qualitativa na pesquisa educacional: retrospectiva e tendências atuais. Perspectiva, 21(2), 431-466.

ZABALZA, Miguel A. (2004) O ensino Universitário: seu cenário e seus protagonistas. Porto Alegre: Artmed.

Recebido em 06/05/2018

Aprovado em 25/06/2018 